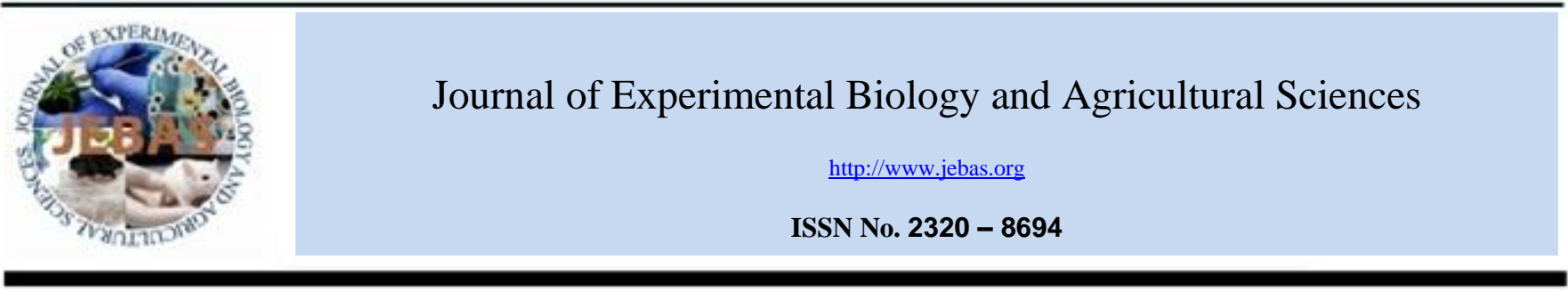

\title{
PARTICULAR BENEFITS CAN BE ATTRIBUTED TO Moringa oleifera LAM LEAVES BASED ON ORIGIN AND STAGE OF MATURITY
}

\author{
Julien Armel ASSIENE AGAMOU ${ }^{1}$, Edith N. FOMBANG ${ }^{*}, 1$ and Carl M. F. MBOFUNG ${ }^{1,2}$ \\ ${ }^{1}$ Department of Food Science and Nutrition (ENSAI), University of Ngaoundere, BP 455, Ngaoundere, Adamawa Region, Cameroon \\ ${ }^{2}$ College of Technology, University of Bamenda, P.O. Box 39, Bambili, North West Region, Cameroon
}

Received - October 08, 2015; Revision - November 01, 2015; Accepted - December 15, 2015

Available Online - December 17, 2015

DOI: http://dx.doi.org/10.18006/2015.3(6).541.555

\begin{abstract}
KEYWORDS
Moringa oleifera leaves

Maturity

Locality

Nutrient composition

Bioactive compounds

Utilisation

ABSTRACT

Chemical compositions of plants are influenced by the environmental conditions under which they are grown. In the present study, Moringa oleifera leaves were collected from eight localities of Cameroon, at two stages of maturity (young and mature). Chemical composition and nutritional benefits of collected plant leaves were studied. Macronutrients and mineral composition of leaves were significantly $(\mathrm{p}=0.0001$ ) influenced by the locality from which they were harvested and the stage of maturity, with significant interactions between them. Principal component analysis was used to group leaves from different localities and at different stages of maturity. Results of the study revealed that mature leaves are richer in proteins, fiber, divalent cations $(\mathrm{Ca}, \mathrm{Mg}, \mathrm{Fe}, \mathrm{Mn}, \mathrm{Cu})$ and bioactive compounds, and thus can be used to combat protein and mineral deficiencies, as well as stress related diseases; while the young leaves are more concentrated in available carbohydrates, total carotenoids, K, $\mathrm{P}$, and $\mathrm{Zn}$; and can be used to combat vitamin A and zinc deficiency, as well as for producing energetic foods. Levels of these components vary with the origin of leaves. Calcium, in particular, was three times higher in mature leaves $(1.58 \%)$ compared to young leaves $(0.59 \%)$, and mature leaves had one and a half times $(20.7 \%)$ more iron than young leaves $(12.5 \%)$. Leaves at different stages of maturity and from different localities are grouped according to their unique nutritional and antioxidant benefits based on their nutrients and bioactive compounds contents.
\end{abstract}

* Corresponding author

E-mail: edfombang@yahoo.fr (Edith N. FOMBANG)

Peer review under responsibility of Journal of Experimental Biology and Agricultural Sciences.

Production and Hosting by Horizon Publisher (http://publisher.jebas.org/index.html).

All rights reserved.
All the article published by Journal of Experimental Biology and Agricultural Sciences is licensed under a Creative Commons Attribution-NonCommercial 4.0 International License Based on a work at www.jebas.org.

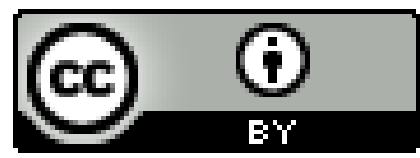




\section{Introduction}

Moringa oleifera $L$. is a tree native to Asia and widely cultivated in sub-Saharan Africa (Armelle et al., 2010; Ogbe \& Affiku, 2011; Agoyi et al., 2014). Leaves of this tree are well appreciated for their nutritional value and their bioactive compounds contents (polyphenols, phytates) (Fahey, 2005; Moyo et al., 2011), which help in the fight against various chronic diseases (Kumar et al., 2010; Biswas et al., 2012; Agoyi et al., 2014). There are evidences that suggested that $M$. oleifera leaf powder could be successfully employed to combat protein and micro-nutrient malnutrition especially in infants and nursing mothers (Oduro et al., 2008; Armelle et al., 2010; Agoyi et al., 2014). It is also useful as a hypotensive and in the prevention of cancer (Fahey, 2005; Oduro et al., 2008; Kumar et al., 2010; Biswas et al., 2012; Agoyi et al., 2014). The virtues of $M$. Oleifera leaves are closely linked to their chemical compositions which in turn are influenced by environmental factors such as soil type and climatic conditions (Jenab et al., 2001; Sarni-Manchado \& Cheynier 2006; Ogbe \& Affiku, 2011). In addition, leaf constituents equally show variation with stage of maturity (Yang et al., 2006; Jongrungruangchok et al., 2010; Bamishaiye et al., 2011) and season of harvest (Yang et al., 2006; Shih et al., 2011). These factors could account for the variability in nutrient composition of M.oleifera leaves observed in the literature. For instance, Moyo et al. (2011), in South Africa, reported protein contents of $30.29 \mathrm{~g}$ per $100 \mathrm{~g}$ DM (Dry Matter) in M. oleifera leaf powders while Ogbe \& Affiku (2011), in Nigeria, reported protein contents of $17.01 \mathrm{~g}$ per $100 \mathrm{~g}$ DM. Variations in nutrient contents of leaves could affect the efficiency of their use.

Cameroon, with a high biodiversity and diversity of foods (Kengué et al., 2008) has experienced an increased growth in the cultivation and consumption of $M$. oleifera leaves throughout the country in the past decade. The leaves are consumed fresh as a vegetable or dried and reduced into powder. The most utilised form is the powder which is added to foods. However, for the production of M. oleifera leaf powder, the leaves are harvested at random with no attention being paid to the stage of maturity or locality of harvest, which could influence the composition of the leaves and consequently their nutritional and therapeutic values. The present study therefore aims at investigating the variation in nutrient composition of M. oleifera leaves harvested from eight different localities in Cameroon, at two stages of maturity and attributing particular benefits to them based on their composition.

\section{Materials and methods}

\subsection{Description of localities}

Leaves of $M$. oleifera were harvested from eight different localities representing 7 of the 10 Regions of Cameroon (Figure 1). The others 3 Regions are areas of low M. oleifera cultivation. The climatic conditions and soil types of these localities are presented in table 1 .

\subsection{Sampling}

Young (bright green coloured leaves at the apex of the branch) and mature (dark green coloured leaves at the base of the branch) leaves of M. oleifera Lam were harvested in August 2012 from all the eight localities in Table 1. These colour differences were selected based on the fact that farmers use them to distinguish between young and mature leaves as it facilitates their comprehension and use as opposed to duration after pruning. Two farms (each at least $1000 \mathrm{~m}^{2}$ ) in each locality, well-kept and without fertilizer application were selected for sampling. Leaves of each maturity stage were collected through a simple random sampling method from both farms early in the morning and pooled together to represent the locality.

Table 1 Climatic conditions and soil type of different localities in Cameroon in August 2012.

\begin{tabular}{|lcccc|}
\hline & Region & $\begin{array}{c}\text { Climatic conditions in August 2012 } \\
\text { Mean Temperature }\left({ }^{\circ} \mathrm{C}\right)\end{array}$ & Soil type \\
& Centre & 220.7 & $23.1(21.0-26.6)$ & Ferralitic \\
\hline Bafia (Gouiffé) & East & 181.2 & $23.1(20.7-27.0)$ & Ferralitic \\
\hline Bertoua (Bonis) & East & 333.1 & $23.0(20.6-26.7)$ & Ferralitic \\
\hline Doumé & West & 250.8 & $18.3(15.7-23.1)$ & Ferralitic \\
\hline Mbouda (Babété) & Littoral & 220.0 & $26.2(24.2-29.5)$ & Yellow soil \\
\hline Edéa & North & 137.1 & $28.6(25.0-34.0)$ & Vertisols \\
\hline Garoua & Far North & 197.3 & $29.9(25.8-36.3)$ & halomorphic \\
\hline Maroua & Adamawa & 247.1 & $21.8(18.9-26.2)$ & Vertisols \\
\hline Méiganga & & & & \\
\hline
\end{tabular}

Source: CMIP 5, MPI-ESM-LR RCP 


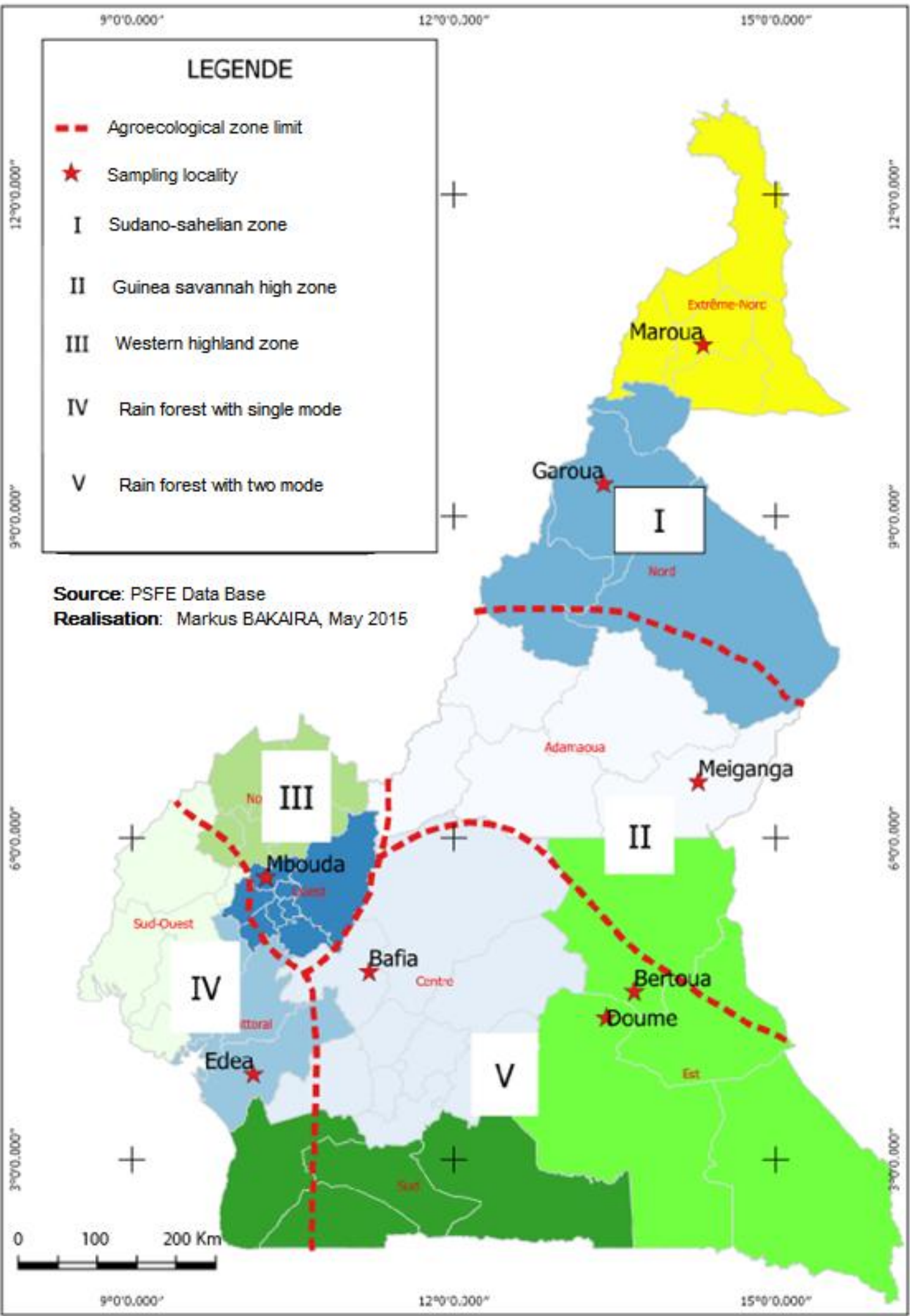

Figure 1 Map of Cameroon showing sampling areas 
2.3 Preparation of powders

After harvesting, leaflets were detached from the leaf, washed with clean water and dried at $55^{\circ} \mathrm{C}$ in an electric dryer (Riviera $\&$ Bar QD105A, Paris, France) for 5 hours. The dried leaves were ground (Zaiba ZB-2225, China) and sieved through a $1 \mathrm{~mm}$ mesh sieve to obtain powder. The powders were then stored in airtight bottles at $4^{\circ} \mathrm{C}$ prior to analysis.

\subsection{Determination of Moisture content}

Moisture content of leaf powders was determined according to AOAC (1990) method.

\subsection{Evaluation of Nutrient composition}

\subsubsection{Total protein, ash and carotenoids content estimation}

Total protein content $(\mathrm{N} \times$ 6.25) was determined using the Kjeldahl method (AOAC, 1990). Similarly, ash content of the dried leaf powder was also determined according to the guide line given by AOAC (1990). Total carotenoids content was estimated according to AOAC (1975) method.

\subsubsection{Available carbohydrates}

Available carbohydrates were determined by the DNS $(3,5$ Dinitrosalicylic acid) method of Fischer \& Stein (1961) following digestion of the samples with $\mathrm{H}_{2} \mathrm{SO}_{4}$ (1.5N) to breakdown carbohydrates to simple sugars.

\subsubsection{Total lipids content}

Total lipids content was determined using the soxhlet method as described by Bourely (1982).

\subsubsection{Minerals contents}

Different minerals like $\mathrm{Ca}, \mathrm{Mg}, \mathrm{K}, \mathrm{Na}, \mathrm{Cu}, \mathrm{Zn}, \mathrm{Mn}$ and $\mathrm{Fe}$ were analysed after extraction by atomic absorption spectrophotometry (Jones \& Vernon, 1990). Phosphorus was analysed using Murphy \& Riley (1962) reagent and read colorimetrically.

\subsubsection{Vitamin C}

Amount of vitamin $\mathrm{C}$ was determined by titrimetric method with some modifications (Tomohiro, 1990). One gram of powder was mixed with $10 \mathrm{ml}$ of acetic acid (90\%). To this was added $5 \mathrm{ml}$ of distilled water and the whole mixed with a magnetic stirrer. Ascorbic acid was evaluated by measuring dehydroascorbic acid obtained after oxidation of ascorbic acid by 2,6dichlorophenol-indophenol. During titration, acetic acid $(10 \%)$ was used as colour indicator and the end of titration was reached when the colour of the solution changed from purplish pink to colourless. Ascorbic acid (10\%) was used as standard and results were expressed as mg ascorbic acid per $100 \mathrm{~g}$ of dry matter.
2.5.6 Total fiber content

Total fiber was determined as described by the method given by Wolff (1968) with little modifications.

2.6 Determination of Bioactive components

2.6.1 Total polyphenols contents

Total polyphenols were determined according to Makkar et al. (1993) with some modification. Ten $(10 \mathrm{ml})$ of ethanol $(70 \%)$ was added to $0.5 \mathrm{~g}$ of powder and the mixture stirred for 2 hours (using a Prolabo 54433 agitator, Paris, France) at 220 rpm, to extract total polyphenols. After centrifuging (DL 6000 mark, rotor $15 \mathrm{~cm}$, Japan) at $3000 \mathrm{~g}$ for $20 \mathrm{~min}$ at $4^{\circ} \mathrm{C}, 0.02 \mathrm{ml}$ of the supernatant was mixed with $0.2 \mathrm{ml}$ of Folin-Ciocalteu reagent diluted (1/16), $0.4 \mathrm{ml}$ of sodium carbonate (20\%) and $1.38 \mathrm{ml}$ distilled water. The mixture was vortexed and incubated in a water bath at $40^{\circ} \mathrm{C}$ for 20 minutes in darkness. Gallic acid $(0.2 \mathrm{~g} / \mathrm{l})$ was used as standard and absorbance was read at $725 \mathrm{~nm}$.

\subsubsection{Total tannins contents}

Total tannins were determined according to Makkar et al. (1993). Polyphenol extract $(1 \mathrm{ml})$ and $1 \mathrm{ml}$ of distilled water were precipitated with $0.1 \mathrm{~g}$ of PVPP (polyvinyl polypyrrolidone) to remove total tannins (100 mg PVPP is sufficient to bind $2 \mathrm{mg}$ of tannins). Total polyphenols in the supernatant was determined as previously described in section 2.6.1 and the total tannins content obtained by difference with the total polyphenols before precipitation.

\subsubsection{Phytates contents}

Phytates were determined as described by Vaintraub \& Lapteva (1988) with some modifications. Phytates were extracted from $0.5 \mathrm{~g}$ of powder suspended in $10 \mathrm{ml}$ of $3.5 \%$ $\mathrm{HCl}$ for 2 hours using a prolabo 54433 agitator Paris, France. The extract was centrifuged (DL 6000, rotor $15 \mathrm{~cm}$, Japan) at $1000 \mathrm{~g}$ for 20 minutes at $10^{\circ} \mathrm{C}$. The supernatant was treated with $1 \mathrm{~g}$ sodium chloride and kept at $4^{\circ} \mathrm{C}$ for 24 hours. This was later centrifuged at $1000 \mathrm{~g}$ for 10 minutes at $10^{\circ} \mathrm{C}$. A $3 \mathrm{ml}$ aliquot of the supernatant was added to $1 \mathrm{ml}$ of modified Wade reagent $\left(0.03 \% \mathrm{FeCl}_{3} 6 \mathrm{H}_{2} \mathrm{O}+0.3 \%\right.$ sulfo-salicylic acid $)$ and centrifuged at $1000 \mathrm{~g}$ for $10 \mathrm{~min}$ at $10{ }^{\circ} \mathrm{C}$. The absorbance was read at $500 \mathrm{~nm}$. Sodium phytate solution $(40 \mu \mathrm{g}$ per ml) was used as standard (100 $\mathrm{g}$ of sodium phytate equals $59.9 \mathrm{~g}$ of phytic acid).

\subsection{Statistical analysis}

Analyses were carried out in triplicates. Microsoft Excel 2010 software was used for calculation of means and standard deviations; Stat-graphic centurion 15.2 software (StatPoint Technologies, Inc, Warrenton, Virginia, USA) for analysis of variance and means separated using the Duncan multiple range test at $\mathrm{P}<0.05$. 
Table 2 Influence of stage of maturity and locality on macronutrients contents of young and mature leaves of M. oleifera (g/100 g DM).

\begin{tabular}{|c|c|c|c|c|c|c|c|}
\hline $\begin{array}{l}\text { Maturity of } \\
\text { leaves }\end{array}$ & Locality & Moisture content & Total proteins & Available carbohydrate & Totall lipids & Total ash & Total Fibers \\
\hline \multirow{9}{*}{$\begin{array}{l}\text { Young } \\
\text { Leaves }\end{array}$} & Bafia & $11.5 \pm 0.5^{t}$ & $20.36 \pm 0.48^{2}$ & $34.86=0.1^{t}$ & $7.64=1.14^{\text {aze }}$ & $9.94 \pm 0.45^{g=}$ & $23.61=1.01^{\mathrm{a}}$ \\
\hline & Bertoua & $10.5 \pm 0.5^{e}$ & $21.51=0.37^{\circ}$ & $36.65=1.74^{32}$ & $9.10=0.10^{\mathrm{de}}$ & $7.18 \pm 0.55^{2}$ & $22.65 \pm 0.55^{\mathrm{es}}$ \\
\hline & Doumé & $11.5 \pm 0.2^{t}$ & $21.88=0.05^{\mathrm{bc}}$ & $37.15=1.17^{2}$ & $8.83=0.05^{d t}$ & $8.89=0.05^{\text {cte }}$ & $20.44=0.55^{\text {s }}$ \\
\hline & Edéa & $9.5 \pm 0.5^{\mathrm{a}}$ & $22.70 \pm 0.54^{\mathrm{eds}}$ & $33.14=1.03^{2}$ & $9.00=0.44^{\mathrm{ds}}$ & $8.06=0.53^{\mathrm{ted}}$ & $23.92=1.34^{\mathrm{de}}$ \\
\hline & Mbouda & $13.5 \pm 0.5^{3}$ & $25.89 \pm 0.09^{=}$ & $33.97=0.22^{\text {et }}$ & $8.53=0.65^{\mathrm{zeds}}$ & $8.02 \pm 0.93^{\text {se }}$ & $21.14=1.71^{\text {ste }}$ \\
\hline & Garoua & $8=0.6^{2}$ & $22.41 \pm 0.13^{\text {zet }}$ & $34.93=0.35^{t}$ & $9.64=1.00^{\mathrm{et}}$ & $9.00 \pm 0.21^{\mathrm{et}}$ & $20.05 \pm 0.16^{2}$ \\
\hline & Maroua & $9 \pm 0.2^{\mathrm{et}}$ & $24.03 \pm 0.48^{\operatorname{tg} z}$ & $34.55=0.82^{\text {et }}$ & $8.16 \pm 0.62^{\text {ted }}$ & $9.49=0.55^{\operatorname{ctg} z}$ & $21.12=0.12^{\text {atc }}$ \\
\hline & Méiganga & $9 \pm 0.5^{\mathrm{ed}}$ & $22.12 \pm 0.01^{\mathrm{sc}}$ & $35.41=0.38^{t z}$ & $6.75=0.53^{2}$ & $9.89=0.05^{\text {tgs }}$ & $22.40=1.63^{\text {tex }}$ \\
\hline & Mean & $10.31=0.44$ & $22.61=0.27$ & $35.08=0.73$ & $8.46 \pm 0.57$ & $8.90=0.45$ & $21.92=0.88$ \\
\hline \multirow{9}{*}{$\begin{array}{l}\text { Matures } \\
\text { Leaves }\end{array}$} & Bafia & $11.5 \pm 0.5^{t}$ & $23.74=0.02^{\text {tz }}$ & $26.90=0.72^{2}$ & $10.78=0.51^{t}$ & $9.15 \pm 0.11^{\text {cts }}$ & $26.21=2.71^{\text {tz }}$ \\
\hline & Bertoua & $9.5 \pm 0.5^{\mathrm{a}}$ & $23.98=0.89^{18 z}$ & $30.70=0.07^{4}$ & $8.15=0.53^{\text {sca }}$ & $6.81=0.11^{2}$ & $27.03=0.44^{\text {tz }}$ \\
\hline & Doumé & $9.5 \pm 0.5^{a}$ & $23.35=1.18^{\text {det }}$ & $28.46=0.18^{z}$ & $10.67 \pm 0.74^{t}$ & $8.95 \pm 0.08^{d z}$ & $25.64=1.24^{\text {et }}$ \\
\hline & Edéa & $7 \pm 0.3^{2}$ & $24.46 \pm 0.95^{8 z}$ & $27.91=0.17^{20}$ & $6.82=0.54^{2}$ & $8.95=0.11^{\mathrm{de}}$ & $27.95=1.65^{8}$ \\
\hline & Mbouda & $12.5 \pm 0.5^{3}$ & $23.55 \pm 0.18^{\text {ets }}$ & $28.27 \pm 1.33^{\Rightarrow}$ & $8.02 \pm 0.04^{\text {zet }}$ & $10.46 \pm 0.05^{2}$ & $26.70=1.04^{\text {t8 }}$ \\
\hline & Garoua & $9 \pm 0.3^{\mathrm{es}}$ & $22.16 \pm 0.91^{\mathrm{sc}}$ & $29.24=0.62^{\text {zed }}$ & $8.64=1.23^{\text {eds }}$ & $10.32 \pm 0.54^{m s}$ & $26.90=0.27^{\text {tg }}$ \\
\hline & Maroua & $10.5 \pm 0.5^{e}$ & $22.72 \pm 0.81^{\text {cas }}$ & $29.95=1.55^{\mathrm{es}}$ & $8.67 \pm 1.21^{\text {cst }}$ & $7.7 \pm 1.09^{2=}$ & $27.58=0.76^{\text {t8 }}$ \\
\hline & Méiganga & $8.5 \pm 0.5^{\mathrm{sc}}$ & $24.95 \pm 0.33^{\mathrm{m}}$ & $28.64 \pm 1.06^{\mathrm{ec}}$ & $7.36 \pm 0.04^{2 z}$ & $8.84 \pm 0.05^{\text {cts }}$ & $26.92 \pm 0.54^{\text {t8 }}$ \\
\hline & Mean & $9.75 \pm 0.45$ & $23.61=0.66$ & $28.76=0.71$ & $8.64=0.60$ & $8.97=0.50$ & $26.87=1.08$ \\
\hline \multirow[t]{3}{*}{ Probability } & Maturity (M) & 0.0365 & 0.0000 & 0.0000 & 0.3795 & 0.5876 & 0.0000 \\
\hline & Locality (L) & 0.0000 & 0.0000 & 0.0000 & 0.0000 & 0.0000 & 0.0071 \\
\hline & Interaction (MI) & 0.0061 & 0.0000 & 0.0053 & 0.0000 & 0.0000 & 0.0917 \\
\hline
\end{tabular}

Values are means \pm standard deviation $(n=3)$. Means in the same column with different superscripts are significantly different from each other $(\mathrm{P}<0.05)$. Values in bold within each stage of maturity represent maximum and minimum contents

Principal component analysis (PCA) was used to group leaves according to their chemical composition. XL-stat 2007 software was used for that purpose.

\section{Results}

\subsection{Moisture contents}

Mean moisture content of young and mature leaf powders of M. Oleifera were 10.31 and $9.75 \mathrm{~g}$ per $100 \mathrm{~g}$ of $\mathrm{DM}$ respectively (Table 2). Moisture content ranged from 8 to $13.50 \%$ in young leaf powders while it ranged from 7 to $12.50 \%$ in mature leaf powders.

\subsection{Macronutrients composition}

\subsubsection{Total protein content}

Mean protein contents were significantly $(\mathrm{p}<0.05)$ higher in mature leaves $(23.61 \mathrm{~g} / 100 \mathrm{~g} \mathrm{DM})$ compared to young leaves (22.61g/100g DM), with the exception of Mbouda and Maroua localities (Table 2). Protein content of leaves was also significantly $(\mathrm{P}=0.0001)$ influenced by locality and stage of maturity, but among these two locality had a greater influence on protein contents, $31.57 \%$ than maturity $11.98 \%$, with their interaction having a cumulative effect $45.04 \%$. Mbouda and Meiganga localities had the highest total protein contents for young $(25.89 \% \mathrm{DM})$ and mature $(24.95 \% \mathrm{DM})$ leaves respectively; whereas Bafia $(20.36 \% \mathrm{DM})$ and Garoua (22.16\% DM) had respectively the lowest.

\subsubsection{Available carbohydrates contents}

Unlike proteins, available carbohydrate contents were significantly $(\mathrm{p}<0.05)$ higher in young leaves $(35.08 \pm 0.73 \mathrm{~g}$ per $100 \mathrm{~g} \mathrm{DM})$ as compared to mature leaves $(28.76 \pm 0.71 \mathrm{~g}$ per 100g DM) (Table 2) for all localities. This is in agreement with the observed significant $(\mathrm{p}=0.0001)$ effect of locality and stage of maturity on total available carbohydrates content, with maturity having a greater influence $83.86 \%$. Available carbohydrate content ranged from $33.14 \%$ to $37.15 \% \mathrm{DM}$ in young leaves while it ranged from $27.91 \%$ to $30.70 \% \mathrm{DM}$ in mature leaves. $M$. oleifera leaves collected from Doume and Bertoua had the highest available carbohydrate contents whereas those from Edea and Bafia had the lowest available contents for young and mature leaves respectively. 
Table 3 Influence of stage of maturity and locality on mineral contents of young and mature leaves of M. Oleifera.

\begin{tabular}{|c|c|c|c|c|c|c|c|c|c|c|c|}
\hline \multirow{2}{*}{\multicolumn{2}{|c|}{ Maturity of leaves }} & \multirow[t]{2}{*}{ Locality } & \multicolumn{5}{|c|}{ Macro-minerals (g/100g DM) } & \multicolumn{4}{|c|}{ Miero- minerals (mg/100g DM) } \\
\hline & & & $\mathbf{C a}$ & Mg & $\mathbf{K}$ & $\mathrm{Na}$ & $\mathbf{P}$ & $\mathrm{Fe}$ & $\mathrm{Zn}$ & Mn & $\mathrm{Cu}$ \\
\hline \multirow{9}{*}{\multicolumn{2}{|c|}{ Young Leaves }} & Bafia & $0.51=0.03^{\mathrm{bc}}$ & $0.33=0.02^{d=f}$ & $2.71=0.27^{\mathrm{hi}}$ & $0.03=0.01^{2}$ & $0.63=0.03^{\mathrm{h}}$ & $14.84=1.02^{\mathrm{ed}}$ & $2.63=0.44^{\mathrm{b}}$ & $4.42=0.75^{\text {edef }}$ & $0.40=0.02^{6 t}$ \\
\hline & & Bertoua & $0.37=0.02^{2:}$ & $0.27=0.02^{258}$ & $1.69=0.17^{* 6}$ & $0.08=0.02^{285}$ & $0.39=0.02^{z}$ & $12.30=0.84^{*}$ & $1.77=0.30^{5 e s}$ & $3.36=0.57$ sest: & $0.32=0.02^{* *}$ \\
\hline & & Doumé & $0.33=0.02^{2}$ & $0.23=0.01^{2}$ & $2.05=0.2^{\mathrm{ses}}$ & $0.07=0.02^{25 e}$ & $0.45=0.02^{\circ}$ & $10.29=0.71^{2}$ & $2.21=0.37^{\mathrm{eet}}$ & $2.44=0.41^{2}$ & $0.30=0.01^{\circ}$ \\
\hline & & Edéa & $0.37=0.02^{2 z}$ & $0.29=0.02^{8 \mathrm{es}}$ & $2.30=0.23^{\text {th }}$ & $0.07=0.02^{258}$ & $0.58=0.03^{\mathrm{stt}}$ & $12.45=0.85^{2}$ & $2.87=0.48^{32}$ & $2.66=0.45^{58}$ & $0.34=0.02^{z=}$ \\
\hline & & Mbouda & $0.68=0.05^{a t}$ & $0.35=0.02^{\mathrm{Et}}$ & $2.95=0.3^{5}$ & $0.43=0.02^{i}$ & $0.65=0.03^{n}$ & $13.83=0.95^{* 6}$ & $3.23=0.54^{2}$ & $3.34=0.56^{\mathrm{mes}}$ & $0.40=0.02^{t 3}$ \\
\hline & & Garoua & $0.83=0.06^{2}$ & $0.29=0.03^{\mathrm{set}}$ & $2.57=0.26^{z}$ & $0.24=0.07^{*}$ & $0.55=0.03^{2}$ & $12.26=0.84^{28}$ & $2.40=0.40^{\text {娄 }}$ & $2.57=0.43^{2 z}$ & $0.30=0.01^{2}$ \\
\hline & & Maroua & $1.03=0.07^{*}$ & $0.35=0.02^{\mathrm{Et}}$ & $2.45=0.24^{57^{*}}$ & $0.18=0.05^{a t}$ & $0.60=0.03^{\mathrm{tg}}$ & $12.51=0.86^{\circ}$ & $2.61=0.44^{37}$ & $4.74=0.80^{\text {atty }}$ & $0.33=0.02^{5 t}$ \\
\hline & & Méiganga & $0.59=0.04^{25}$ & $0.28=0.03^{56}$ & $2.55=0.25^{z=}$ & $0.10=0.03^{* 6}$ & $0.56=0.03^{\mathrm{st}}$ & $12.24=0.84^{28}$ & $1.98=0.33^{\mathrm{ese}}$ & $2.70=0.45^{28}$ & $0.30=0.01^{8}$ \\
\hline & & Mean & $0.59=0.04$ & $0.30=0.02$ & $2.41=0.24$ & $0.15=0.03$ & $0.55=0.03$ & $12.59=0.86$ & $2.46=0.41$ & $3.28=0.55$ & $0.34=0.02$ \\
\hline \multirow{9}{*}{\multicolumn{2}{|c|}{ Mature Leaves }} & Bafia & $1.63=0.12^{5}$ & $0.52=0.03^{3}$ & $2.11=0.21^{\mathrm{def}}$ & $0.07=0.02^{\mathrm{se}}$ & $0.54=0.03^{i}$ & $19.41=1.33^{=f}$ & $1.91=0.32^{\mathrm{bed} z}$ & $11.62=1.97^{\mathrm{i}}$ & $0.45=0.03^{h}$ \\
\hline & & Bertoua & $1.36=0.10^{*}$ & $0.33=0.02^{\mathrm{set}}$ & $1.18=0.11^{2}$ & $0.04=0.01^{2 z}$ & $0.27=0.01^{2}$ & $19.12=1.31^{\circ}$ & $0.93=0.15^{2}$ & $5.95=1.00^{37}$ & $0.36=0.02^{25:}$ \\
\hline & & Doumé & $1.83=0.14$ & $0.34=0.02^{\mathrm{Et}}$ & $1.64=0.16^{2}$ & $0.23=0.07^{*}$ & $0.40=0.02^{\circ}$ & $19.36=1.33^{\mathrm{tt}}$ & $1.38=0.23^{2 z}$ & $6.46=1.09^{=}$ & $0.38=0.02^{\mathrm{etz}}$ \\
\hline & & Edéa & $1.19=0.09^{3}$ & $0.49=0.03^{3}$ & $1.57=0.15^{\circ}$ & $0.09=0.02^{258}$ & $0.61=0.03^{\mathrm{tz}=}$ & $22.57=1.55^{*}$ & $2.07=0.35^{\mathrm{etet}}$ & $4.79=0.81^{\mathrm{etg}}$ & $0.39=0.02^{\mathrm{Et}}$ \\
\hline & & Mbouda & $1.84=0.14$ & $0.57=0.04^{2}$ & $2.29=0.23^{\text {tig }}$ & $0.19=0.05^{a z}$ & $0.42=0.02^{: *}$ & $22.54=1.55^{n}$ & $1.86=0.31^{\text {sest }}$ & $5.14=0.87^{18}$ & $0.41=0.02^{172}$ \\
\hline & & Garoua & $1.18=0.09^{18}$ & $0.31=0.02^{\mathrm{st}}$ & $2.18=0.22^{\mathrm{set}}$ & $0.20=0.06^{\mathrm{z}}$ & $0.45=0.02^{\circ}$ & $16.42=1.13^{a}$ & $1.73=0.29^{\mathrm{ses}}$ & $3.04=0.51^{204}$ & $0.25=0.01^{2}$ \\
\hline & & Maroua & $1.84=0.14$ & $0.37=0.02^{7}$ & $1.90=0.19^{\text {sea }}$ & $0.13=0.03^{\mathrm{a}}$ & $0.43=0.02^{26}$ & $25.09=1.73^{5}$ & $1.53=0.25^{256}$ & $5.86=0.99^{3 *}$ & $0.43=0.03^{32}$ \\
\hline & & Méiganga & $1.76=0.13^{y}$ & $0.26=0.01^{28}$ & $2.17=0.22^{\mathrm{st}}$ & $0.09=0.02^{258}$ & $0.41=0.02^{z *}$ & $21.26=1.46^{z}$ & $1.55=0.26^{26}$ & $3.99=0.67^{\text {sestet }}$ & $0.34=0.02^{\mathrm{st}}$ \\
\hline & & Mean & $1.58=0.12$ & $0.40=0.03$ & $1.88=0.19$ & $0.13=0.03$ & $0.44=0.02$ & $20.72=1.43$ & $1.62=0.27$ & $5.86=0.99$ & $0.38=0.02$ \\
\hline \multirow[t]{3}{*}{ Probability } & & urity $(M)$ & 0.0000 & 0.0000 & 0.0000 & 0.1910 & 0.0000 & 0.0000 & 0.0000 & 0.0000 & 0.0000 \\
\hline & & ality (L) & 0.0000 & 0.0000 & 0.0000 & 0.0000 & 0.0000 & 0.0000 & 0.0000 & 0.0000 & 0.0000 \\
\hline & Int & ction (MI) & 0.0000 & 0.0000 & 0.8236 & 0.0000 & 0.0000 & 0.0000 & 0.5029 & 0.0000 & 0.0003 \\
\hline
\end{tabular}


Table 4 Influence of stage of maturity and locality on total carotenoids and vitamin C contents in young and mature leaves of M. oleifera $(\mathrm{mg} / 100 \mathrm{~g} \mathrm{DM})$.

\begin{tabular}{|c|c|c|c|}
\hline Maturity of leaves & Locality & Total carotenoids & Vitamin C \\
\hline \multirow[t]{9}{*}{ Young Leaves } & Bafia & $88.20 \pm 1.72^{\mathrm{d}}$ & $56.43 \pm 1.32^{\mathrm{i}}$ \\
\hline & Bertoua & $83.01 \pm 1.55^{\mathrm{c}}$ & $58.27 \pm 1.13^{\mathrm{i}}$ \\
\hline & Doumé & $116.41 \pm 1.12^{\mathrm{j}}$ & $44.15 \pm 1.29^{\mathrm{bc}}$ \\
\hline & Edéa & $129.19 \pm 0.54^{\mathrm{k}}$ & $39.33 \pm 1.42^{\mathrm{a}}$ \\
\hline & Mbouda & $153.06 \pm 1.74^{1}$ & $50.53 \pm 1.51^{\mathrm{fg}}$ \\
\hline & Garoua & $115.07 \pm 1.54^{\mathrm{ij}}$ & $58.27 \pm 0.80^{\mathrm{i}}$ \\
\hline & Maroua & $106.45 \pm 1.28^{\mathrm{f}}$ & $46.61 \pm 1.31^{\text {cde }}$ \\
\hline & Méiganga & $108.31 \pm 1.53^{\mathrm{fg}}$ & $48.16 \pm 1.28^{\mathrm{ef}}$ \\
\hline & Mean & $112.46 \pm 1.38$ & $50.22 \pm 1.26$ \\
\hline \multirow[t]{9}{*}{ Mature Leaves } & Bafia & $109.24 \pm 1.15^{\mathrm{gh}}$ & $53.28 \pm 1.49^{\mathrm{h}}$ \\
\hline & Bertoua & $66.98 \pm 0.85^{\mathrm{a}}$ & $58.43 \pm 1.96^{\mathrm{i}}$ \\
\hline & Doumé & $94.83 \pm 1.44^{\mathrm{e}}$ & $43.49 \pm 1.65^{\mathrm{b}}$ \\
\hline & Edéa & $86.19 \pm 1.11^{\mathrm{d}}$ & $45.45 \pm 1.62^{\mathrm{bcd}}$ \\
\hline & Mbouda & $113 \pm 1.91^{\mathrm{i}}$ & $51.62 \pm 2.37^{\text {gh }}$ \\
\hline & Garoua & $111.46 \pm 1.94^{\mathrm{h}}$ & $61.31 \pm 0.95^{\mathrm{j}}$ \\
\hline & Maroua & $79.33 \pm 0.28^{b}$ & $45.52 \pm 1.61^{\mathrm{bcd}}$ \\
\hline & Méiganga & $80.17 \pm 0.84^{b}$ & $47.13 \pm 1.29^{\mathrm{de}}$ \\
\hline & Mean & $92.77 \pm 1.19$ & $50.78 \pm 1.62$ \\
\hline \multirow[t]{3}{*}{ Probability } & (M) & 0,0000 & 0,2020 \\
\hline & $(L)$ & 0,0000 & 0,0000 \\
\hline & $(M L)$ & 0,0000 & 0,0003 \\
\hline
\end{tabular}

Values are means \pm standard deviation $(\mathrm{n}=3)$. Means in the same column with different superscripts are significantly different from each other $(\mathrm{P}<0.05)$; Values in bold within each stage of maturity represent maximum contents.

\subsubsection{Total lipids contents}

Young $(8.46 \pm 0.57 \mathrm{~g}$ per $100 \mathrm{~g} \mathrm{DM})$ and mature leaves $(8.64 \pm$ $0.60 \mathrm{~g}$ per $100 \mathrm{~g} \mathrm{DM})$ did not shows any significant differences in lipid contents and accordingly maturity had no significant $(\mathrm{p}=0.37)$ influence on lipids contents (table 2). Locality however, significantly $(\mathrm{p}=0.0001)$ influenced lipid content as there exists significant differences between localities for the same maturity stage.

\subsubsection{Total ash}

Young and mature leaves had mean total ash contents of $8.90 \pm$ 0.45 and $8.97 \pm 0.50$ g per $100 \mathrm{~g}$ DM respectively (table 2) with no significant $(\mathrm{p}>0.05)$ difference between them. However from one locality to another there was significant difference $(\mathrm{p}=0.0001)$ in ash content.

\subsubsection{Total fiber contents}

Fiber are the non-digestible polysaccharide residues of plants, and mean total fiber was significantly $(\mathrm{p}<0.05)$ higher in mature leaves $(26.87 \pm 1.08 \mathrm{~g}$ per $100 \mathrm{~g} \mathrm{DM})$ compared to young leaves $(21.92 \pm 0.88 \mathrm{~g}$ per $100 \mathrm{~g} \mathrm{DM})$. Locality and stage of maturity had significant $(\mathrm{p}=0.0001)$ effects on fiber contents (table 5), with maturity it contributing more $(74.49 \%)$ to the effects than locality. However, the locality of Edea had the highest total fiber for both stages maturity.

\subsection{Mineral and Vitamin composition}

\subsubsection{Macro-minerals (Ca, $\mathrm{Mg}, \mathrm{K}, \mathrm{Na}, \mathrm{P})$}

The mineral composition of $M$. oleifera leaf powders from different localities are presented on Table 3. Mean contents of macro-minerals (g per $100 \mathrm{~g} \mathrm{DM}$ ) in young and mature leaves were respectively 0.59 and 1.58 for $\mathrm{Ca} ; 0.30$ and 0.40 for $\mathrm{Mg}$; 2.41 and 1.88 for $\mathrm{K} ; 0.15$ and 0.13 for $\mathrm{Na} ; 0.55$ and 0.44 for $\mathrm{P}$. Magnesium was significantly $(\mathrm{p}<0.05)$ higher in mature leaves whereas potassium and phosphorus presented significantly $(\mathrm{p}<0.05)$ higher contents in young leaves. Sodium content remained unchanged with maturity, whereas Calcium content tripled in mature leaves compared to young leaves. Leaf macro-mineral composition was significantly $(\mathrm{p}=0.0001)$ influenced by locality and stage of maturity, with the exception of sodium where only locality had a significant influence. 
However when we consider the sum of squares of these two factors we realise that locality has a greater effect on magnesium $(46.21 \%)$, potassium $(55 \%)$, sodium $(60.41 \%)$ and phosphorus $(56.39 \%)$ contents, whereas maturity has a greater influence on calcium content $(77.91 \%)$ which is evident in the tripling of calcium content with maturity. Considering the young leaves, the locality of Mbouda has the highest concentration of the different macro-minerals, with the exception of calcium.

\subsubsection{Micro-minerals (Fe, $\mathrm{Zn}, \mathrm{Mn}, \mathrm{Cu})$}

Micro-minerals ( $\mathrm{Fe}, \mathrm{Zn}, \mathrm{Mn}, \mathrm{Cu}$ ) content was also significantly $(\mathrm{p}=0.0001)$ influenced by locality and stage of maturity. Maturity had a greater influence on iron (77.18\%) and zincs $(42.40 \%)$ contents, whereas locality had a greater influence on manganese $(41.39 \%)$ and copper $(62.51 \%)$ contents. Iron, manganese and copper are more concentrated in mature leaves compared to young leaves which are more concentrated in zinc. Young and mature leaves of $M$. oleifera have respectively mean contents (mg per $100 \mathrm{~g} \mathrm{DM}$ ) of 12.59 and 20.72 for Fe; 2.46 and 1.62 for $\mathrm{Zn} ; 3.28$ and 5.86 for $\mathrm{Mn} ; 0.34$ and 0.38 for $\mathrm{Cu}$. Mbouda and Maroua localities had highest iron contents in young and mature leaves respectively. Mbouda had equally highest concentration of micro-minerals for young leaves, except in the case of manganese.

\subsubsection{Total carotenoids contents}

Except in Bafia, carotenoids were significantly $(\mathrm{p}<0.05)$ more concentrated in young leaves compared to mature leaves. Locality and maturity both had significant $(\mathrm{p}=0.0001)$ influences on carotenoids contents, with locality accounting for $(57.20 \%)$ of this effect. Mean total carotenoids contents in young and mature leaves of $M$. oleifera were $112.46 \pm 1.38$ and $92.77 \pm 1.19 \mathrm{mg}$ per $100 \mathrm{~g} \mathrm{DM}$ respectively (table 4). Mbouda locality had the highest total carotenoids contents at both maturity stages.

\subsubsection{Vitamin $\mathrm{C}$ contents}

The stage of maturity of the leaves had no significant $(\mathrm{p}=0.20)$ effect on their vitamin $\mathrm{C}$ content, but this was significantly $(\mathrm{p}=0.0001$ ) influenced by the origin (locality) of the leaves. Young and mature leaves had vitamin $\mathrm{C}$ contents of $50.22 \pm$ 1.26 and $50.78 \pm 1.62 \mathrm{mg}$ per $100 \mathrm{~g} \mathrm{DM}$ respectively (table 4 ).

3.4 Bioactive compounds (Total polyphenols, Tannins, Phytates)

Table 5 shows the bioactive compound contents of M. oleifera leaf powders collected from the eight different localities. Neither the origin of the leaves, nor the stage of maturity had any significant $(\mathrm{p}>0.05)$ influence on polyphenols and tannin contents with essentially the same values between localities and between maturities. Mean total polyphenols contents in young and mature leaves were $1.12 \pm 0.04$ and $1.17 \pm 0.04 \mathrm{~g}$ per $100 \mathrm{~g}$ DM respectively. Among the young leaves, the locality of Bafia had the highest concentration of bioactive compounds.

Tannins contents of young and mature leaves were $0.42 \pm 0.04$ and $0.47 \pm 0.05 \mathrm{~g}$ per $100 \mathrm{~g}$ DM respectively (table 5 ) and no significant $(\mathrm{p}>0.05)$ difference was reported between these two. Tannins were positively correlated with total polyphenol $(\mathrm{r}=0.867 ; \mathrm{p}<0.05$, Table 7).

On the contrary, the individual effect of locality and maturity as well as the interaction between them significantly $(p=0.0001)$ influenced phytates content obtained in this study; but the sum of squares of each factor indicated that locality had a greater influence $(59 \%)$. Mean phytate contents were significantly $(\mathrm{p}<0.05)$ higher in mature leaves (340.04) compared to young leaves (312.77) mg per $100 \mathrm{~g} \mathrm{DM}$ (table 5). The locality of Bafia had the highest phytate content for both young and mature leaves. Phytates in this study, show a significant negative correlation with zinc $(r=-0.574, p<0.05$, Table 7).

\section{Discussions}

4.1 Chemical composition of $M$. oleifera as influenced by locality and maturity

\subsubsection{Macronutrients}

The locality from which leaves were harvested and their maturity stage had a significant $(\mathrm{p}=0.001)$ influence on their macronutrients composition (proteins, available carbohydrates, fiber), with the exception of ash and lipid contents which were only significantly $(\mathrm{p}=0.001)$ affected by locality (table 2 ). Protein contents of leaves are usually influenced by soil nitrogen content, and soil nitrogen varies from one locality to another and with soil type thereby affecting plant nitrogen concentration. Nitrogen is used for the synthesis of amino acids and proteins which are stored in leaves and other parts of the plant (Folly, 2000).

Plants use these reserves for their growing needs. Young leaves, being at a more active stage of growth, will use much of these reserves for their growth (Zufferey, 2000), reason for the significant $(\mathrm{p}<0.05)$ lower protein contents observed in young leaves $(22.61 \%)$ compared to mature leaves $(23.61 \%)$. Values of protein recorded in this study are similar to those of Shih et al. (2011) in Taiwan but lower than the 28.34 and $31.08 \%$ DM reported earlier by Yang et al. (2006) respectively for young and mature leaves in Taïwan. However, the fact that mature leaves had higher protein contents compared to young leaves is consistent with present study observations. $M$. oleifera proteins are said to be of good quality as SánchezMachado et al. (2010) in Mexico had reported that they are rich in the essential amino acids with the exception of methionine which is generally deficient in green leaves. 
Table 5 Influence of stage of maturity and locality on bioactive compounds in M. oleifera leaf powder (g/100gDM).

\begin{tabular}{|c|c|c|c|c|}
\hline Maturity of leaves & Locality & Total polyphenols & Total tannins & Phytates* \\
\hline \multirow[t]{9}{*}{ Young Leaves } & Bafia & $1.67 \pm 0.04^{\mathrm{c}}$ & $0.72 \pm 0.03^{\mathrm{c}}$ & $339.61 \pm 2.87^{\mathrm{h}}$ \\
\hline & Bertoua & $1.03 \pm 0.01^{\mathrm{abcd}}$ & $0.36 \pm 0.04^{\mathrm{abc}}$ & $326.58 \pm 2.81^{\mathrm{ef}}$ \\
\hline & Doumé & $1.12 \pm 0.07^{\mathrm{abcd}}$ & $0.41 \pm 0.08^{\mathrm{abc}}$ & $314.30 \pm 2.12^{\mathrm{c}}$ \\
\hline & Edéa & $0.90 \pm 0.03^{\mathrm{a}}$ & $0.61 \pm 0.01^{\mathrm{abc}}$ & $277.77 \pm 1.79^{\mathrm{a}}$ \\
\hline & Mbouda & $1.03 \pm 0.08^{\mathrm{abc}}$ & $0.23 \pm 0.07^{\mathrm{a}}$ & $313.65 \pm 3.96^{\mathrm{c}}$ \\
\hline & Garoua & $1.01 \pm 0.03^{\mathrm{abc}}$ & $0.29 \pm 0.04^{\mathrm{abc}}$ & $281.44 \pm 1.05^{\mathrm{a}}$ \\
\hline & Maroua & $0.95 \pm 0.03^{\mathrm{ab}}$ & $0.26 \pm 0.05^{\mathrm{ab}}$ & $323.40 \pm 3.87^{\mathrm{de}}$ \\
\hline & Méiganga & $1.23 \pm 0.08^{\mathrm{bcd}}$ & $0.51 \pm 0.07^{\mathrm{abc}}$ & $325.44 \pm 3.79^{\text {def }}$ \\
\hline & Mean & $1.12 \pm 0.04$ & $0.42 \pm 0.04$ & $312.77 \pm 2.78$ \\
\hline \multirow[t]{9}{*}{ Mature Leaves } & Bafia & $1.16 \pm 0.06^{\mathrm{abcd}}$ & $0.55 \pm 0.09^{\mathrm{abc}}$ & $366.29 \pm 2.82^{\mathrm{i}}$ \\
\hline & Bertoua & $1.33 \pm 0.03^{\mathrm{d}}$ & $0.51 \pm 0.06^{\mathrm{abc}}$ & $364.92 \pm 1.19^{\mathrm{i}}$ \\
\hline & Doumé & $1.18 \pm 0.01^{\mathrm{abcd}}$ & $0.50 \pm 0.08^{\mathrm{abc}}$ & $362.83 \pm 3.92^{\mathrm{i}}$ \\
\hline & Edéa & $1.28 \pm 0.08^{\mathrm{cd}}$ & $0.70 \pm 0.08^{\mathrm{bc}}$ & $304.17 \pm 1.40^{\mathrm{b}}$ \\
\hline & Mbouda & $1.08 \pm 0.05^{\text {abcd }}$ & $0.23 \pm 0.02^{\mathrm{a}}$ & $321.77 \pm 1.92^{\mathrm{d}}$ \\
\hline & Garoua & $1.03 \pm 0.01^{\mathrm{abc}}$ & $0.33 \pm 0.03^{\mathrm{abc}}$ & $331.52 \pm 1.81^{\mathrm{g}}$ \\
\hline & Maroua & $1.08 \pm 0.02^{\mathrm{abcd}}$ & $0.42 \pm 0.01^{\mathrm{abc}}$ & $340.65 \pm 1.83^{\mathrm{h}}$ \\
\hline & Méiganga & $1.23 \pm 0.08^{\mathrm{bcd}}$ & $0.55 \pm 0.03^{\mathrm{abc}}$ & $328.14 \pm 1.90^{\mathrm{fg}}$ \\
\hline & Mean & $1.17 \pm 0.04$ & $0.47 \pm 0.05$ & $340.04 \pm 2.10$ \\
\hline \multirow[t]{3}{*}{ Probability } & Maturity $(M)$ & 0.4897 & 0.1767 & 0.0000 \\
\hline & Locality $(L)$ & 0.1849 & 0.2588 & 0.0000 \\
\hline & Interaction $(M L)$ & 0.2106 & 0.5461 & 0.0000 \\
\hline
\end{tabular}

Values are means \pm standard deviation $(\mathrm{n}=3)$. Means in the same column with different superscripts are significantly different from each other $(\mathrm{P}<0.05)$; *mg/100 g DM; Values in bold within each stage of maturity represent maximum contents.

Plant leaves are the site for photosynthetic activity which produces carbohydrates for energy and other needs of the plant. According to Zufferey (2000) this photosynthetic activity is more intense in young leaves in active stage of growth and needing more nutrients for growth, compared to mature ageing leaves. This explains why available carbohydrates were systematically significantly $(\mathrm{p}<0.05)$ higher in young leaves $(35.08 \%)$ compared to mature leaves $(28.76 \%)$ of $M$. oleifera for each locality (table 2), and why maturity had a greater influence $83.86 \%$ on carbohydrate content than locality. Available carbohydrate contents of young leaves in this study are closer to the range of 35.7 to $43.3 \mathrm{~g}$ per $100 \mathrm{~g}$ DM reported by Yameogo et al. (2011) for $M$. oleifera leaves in Burkina Faso. Similar observations of higher carbohydrates content in young leaves compared to mature leaves of M. oleifera have been made by Yang et al. (2006) in Taïwan; and by Bamishaiye et al. (2011) in Nigeria.

Lipid contents for young and mature leaves were high $(8.46 \pm$ 0.57 and $8.64 \pm 0.60 \mathrm{~g}$ per $100 \mathrm{~g} \mathrm{DM})$ with no significant differences between maturities. These values are within the range of 4 to $9 \%$ DM reported by Sánchez-Machado et al. (2010) in leaves of M. oleifera in Mexico. M. oleifera leaf lipids appear to be of good nutritional quality as they have been reported to be rich in unsaturated fatty acids (70\%) (Sánchez-Machado et al., 2010).

Fibers are more elaborated in mature plant organs (Foulk et al., 2011) given that mature leaves have in addition to a primary cell wall (made up of fiber - pectin, cellulose, hemi cellulose), a rigid secondary cell wall which is also constituted of several fibers - lignin, and cellulose (Cheftel et al., 1984). Therefore, even though locality and maturity had significant $(\mathrm{p}=0.0001)$ effects on fiber contents (table 5), maturity contributed more $(74.49 \%)$ of the effects than locality. Fiber contents in this study ranged from 20.05 to $27.95 \mathrm{~g}$ per $100 \mathrm{~g} \mathrm{DM}$ and are in agreement with the range of 19.2 to $30 \%$ obtained by Oduro et al. (2008) and Sánchez-Machado et al. (2010) in M. oleifera leaf powder from Ghana and Mexico respectively.

Plants obtain their minerals from the soil, and climatic conditions and minerals contents of soils differ from one locality to another and with soil type (Kengué et al., 2008) thereby influencing the mineral contents of plants. This is supported by the significant $(\mathrm{p}=0.0001)$ effect of locality on ash content. Ash contents of M. oleifera leaves in this study are high $(>8 \%)$, indicating a high concentration of minerals (table $2)$ with no significant $(p>0.05)$ difference between maturities. Similar values of ash were reported by Jongrungruangchok et al. (2010) and Shih et al. (2011) with M. oleifera leaves in Thailand and Taiwan respectively.

\subsubsection{Macro minerals (Ca, Mg, $\mathrm{K}, \mathrm{Na}, \mathrm{P})$}

Macro minerals composition was significantly $(\mathrm{p}=0.0001)$ influenced by locality and maturity, with the exception of sodium which was only significantly affected by locality. 
The absorption of minerals by plants from the soil changes with maturity of plants and in accordance with their role in leaves. Consequently, higher concentration of magnesium in mature leaves could be attributed to chlorophyll which contains magnesium in its structure, and accumulates in leaves as they mature (Folly, 2000). Higher calcium content in mature leaves $(1.58 \mathrm{~g}$ per $100 \mathrm{~g} \mathrm{DM})$ may be due to its role in the calcium- fiber (pectin) network which contributes in ensuring the rigidity of the secondary cell wall (Cheftel et al., 1984; Kirkby \& Pilbeam, 1984). A positive correlation $(r=0.740$; $\mathrm{p}<0.05$, table 7) obtained between calcium and fiber supports this assertion. Values of calcium are similar to $(0.54 \mathrm{~g}$ per 100 g DM), but lower than (2.04 g per $100 \mathrm{~g} \mathrm{DM})$ that reported by Yang et al. (2006) respectively in young and mature leaves of M. oleifera in Taiwan.

\subsubsection{Micro minerals (Fe, $\mathrm{Zn}, \mathrm{Mn}, \mathrm{Cu}$ )}

Maturity had a greater influence on iron $(77.18 \%)$ and zinc $(42.40 \%)$ contents, whereas locality had a greater influence on manganese $(41.39 \%)$ and copper $(62.51 \%)$ contents. Iron, manganese and copper are more concentrated in mature leaves whereas young leaves are more concentrated in zinc (table 3). Minerals contribute to several reactions in plants which influences their composition. Iron was the most abundant micro-mineral in $M$. oleifera leaf powders. Iron participates in photosynthesis and is a constituent of many enzymes while zinc and copper are cofactors in many reactions (Koolman \& Roehm, 2005). Iron contents of young and mature leaves are respectively lower than those reported by Yang et al. (2006), 18.54 and $30.18 \mathrm{mg}$ per $100 \mathrm{~g} \mathrm{DM}$, for young and mature leaves of M. oleifera in Taiwan. The mean content of zinc is in the range of 1.5 to $3 \mathrm{mg}$ per $100 \mathrm{~g}$ DM reported by Armelle et al. (2010) whereas copper and manganese have values below the range reported by these authors.

\subsubsection{Vitamins}

Carotenoids (precursor of vitamin A) are responsible for most of the yellow, orange and red colour of fruits and vegetables (Folly, 2000). They also occur along with chlorophyll in chloroplasts. They are the underlying pigments in green leaves which become visible when chlorophyll is destroyed (Belitz et al., 2009). Carotenoids content was higher in young leaves $(112.46 \pm 1.38 \mathrm{mg}$ per $100 \mathrm{~g} \mathrm{DM})$, and could be related to its photo-protective role in photosynthesis which would be most intense in young leaves (Zufferey, 2000; Koolman \& Roehm, 2005). Mean total carotenoids contents of young (112.46) and mature leaves (92.77) of M. oleifera in this study, compare to values (101) mg per $100 \mathrm{~g}$ DM recorded by Djuikwo et al. (2011), for M. oleifera leaves from Bini-Dang (Ngaoundere).

Vitamin $\mathrm{C}$ is a heat labile vitamin and thus its contents could have been affected by the drying process. However, mean vitamin $\mathrm{C}$ contents of young and mature leaves in this study are in the range of $15-100 \mathrm{mg}$ per $100 \mathrm{~g} \mathrm{DM}$ obtained by Armelle et al. (2010) in M. oleifera leaf powders from Ghana.

\subsubsection{Bioactive compounds}

Polyphenols and tannins were not significantly affected by either maturity of leaves or locality. Tannins were significantly positively correlated with polyphenol $(r=0.867 ; \mathrm{p}<0.05$, Table 7 ), which is expected as tannins are a component of polyphenol. Polyphenols have been lauded for their beneficial effects in the fight against chronic diseases like atherosclerosis, diabetes (Fahey, 2005; Biswas et al., 2012). Mean total polyphenol contents obtained in this study are within the range of 0.67 to $2.02 \mathrm{~g}$ per $100 \mathrm{~g}$ DM obtained by Tchiégang \& Kitikil (2004) and Moyo et al. (2011) with M. oleifera leaf powder.

Table 6 Groupings of M. oleifera leaf powders from different localities and maturities according to chemical composition and their potential applications.

\begin{tabular}{|c|c|c|c|}
\hline $\begin{array}{l}\text { M. oleifera leaf } \\
\text { powder Groups }\end{array}$ & Composition of $M$. oleifera leaf powder Groups & Major components & Potential uses \\
\hline Group 1 & $\begin{array}{l}\text { Mature leaves of } M \text {. oleifera from Mbouda (MLMB), } \\
\text { Bafia (MLBA), Edea (MLED), Maroua (MLMA), Doume } \\
\text { (MLDO) and Meiganga (MLME) }\end{array}$ & $\begin{array}{l}\text { Total proteins } \\
\mathrm{Mg}, \mathrm{Cu}, \mathrm{Mn}, \mathrm{Ca}, \mathrm{Fe} \\
\text { Total fibers }\end{array}$ & $\begin{array}{l}\text { Minerals and protein } \\
\text { deficiencies. }\end{array}$ \\
\hline Group 2 & Mature leaves of M. oleifera from Bertoua (MLBE) & $\begin{array}{l}\text { Phytates } \\
\text { Total tannins } \\
\text { Total polyphenols }\end{array}$ & Antioxidants \\
\hline Group 3 & $\begin{array}{l}\text { Young leaves of } M \text {. oleifera from Bertoua (YLBE), Bafia } \\
\text { (YLBA), Meiganga (YLME), Doume (YLDO) }\end{array}$ & $\begin{array}{l}\text { Available } \\
\text { carbohydrates }\end{array}$ & $\begin{array}{l}\text { Energetic foods and } \\
\text { Beverages }\end{array}$ \\
\hline Group 4 & $\begin{array}{l}\text { Young leaves of } \text { M. oleifera from Mbouda (YLMB), } \\
\text { Maroua (YLMA), Edea (YLED) and Garoua (YLGA) }\end{array}$ & $\begin{array}{l}\text { Total carotenoids } \\
\mathrm{Na}, \mathrm{Zn}, \mathrm{K}, \mathrm{P}\end{array}$ & $\begin{array}{l}\text { Antioxidants and } \\
\text { Vitamin A deficiency }\end{array}$ \\
\hline Group 5 & Mature leave of M. oleifera of Garoua (MLGA) & $\begin{array}{l}\text { Total ash } \\
\text { Total lipids } \\
\text { Vitamin C }\end{array}$ & $\begin{array}{l}\text { Antioxidants and } \\
\text { Nutritional }\end{array}$ \\
\hline
\end{tabular}




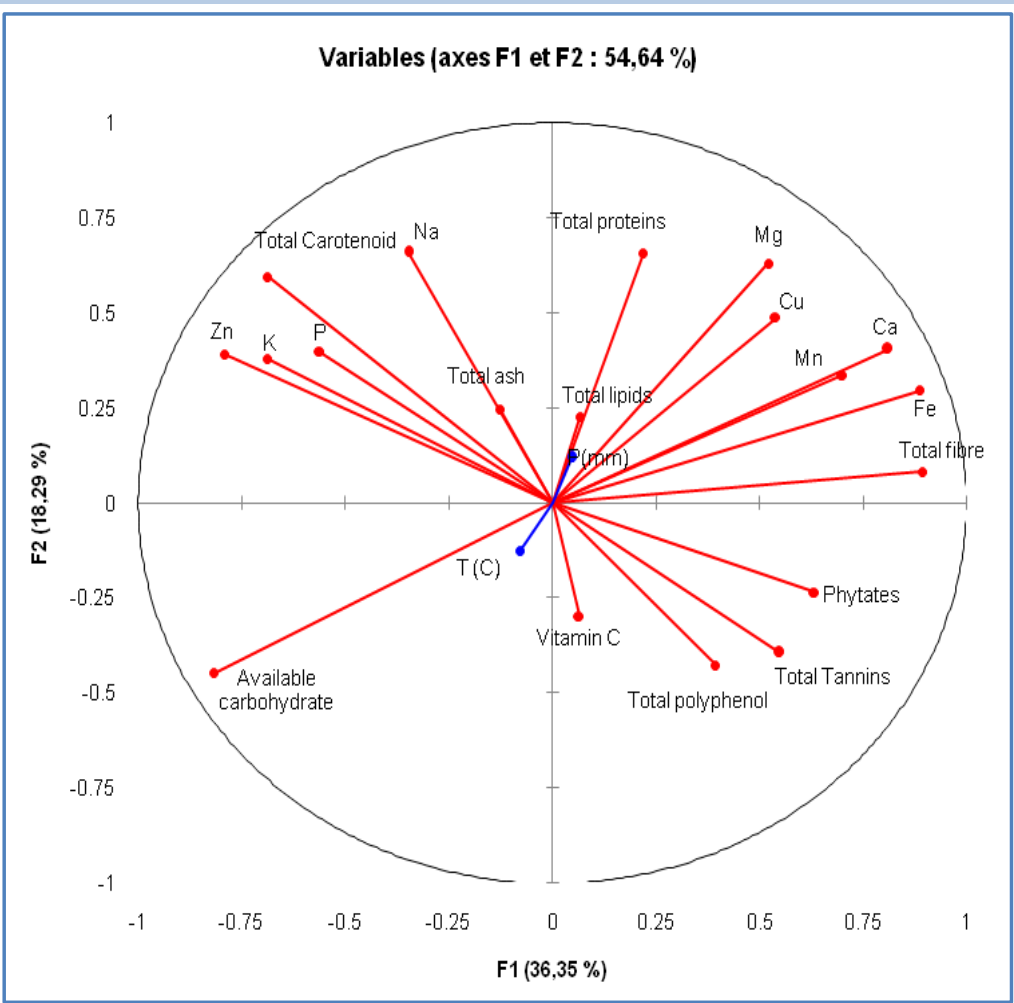

Figure 2a Correlation circle of similarities between nutrients and bioactive compounds of $M$. oleifera leaf powders [Temperature $\left(\mathrm{T}{ }^{\circ} \mathrm{C}\right)$ and Precipitation (p $\mathrm{mm}$ ) are supplementary variables].

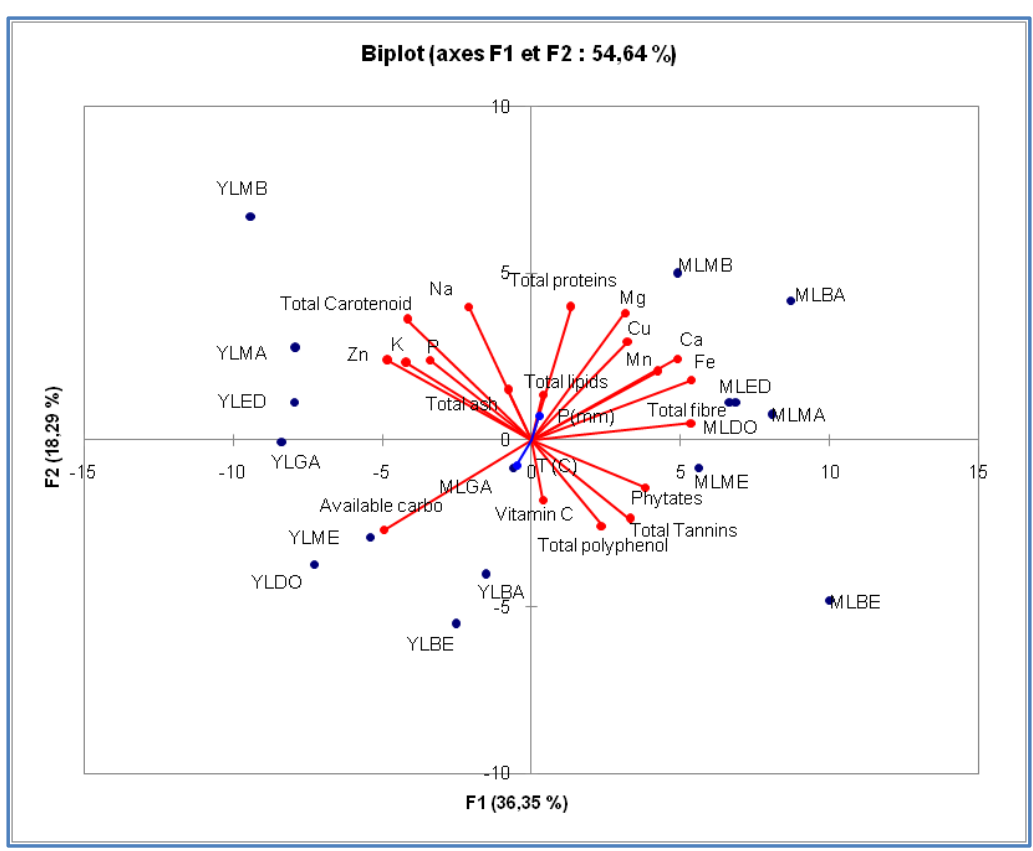

(MLBA/YLBA: Mature Leaves/Young Leaves from Bafia ; MLBE/YLBE : Mature Leaves/Young Leaves from Bertoua ; MLDO/YLDO :Mature Leaves/Young Leaves from Doumé; MLMB/YLMB :Mature Leaves/Young Leaves from Mbouda ; MLED/YLED : Mature Leaves/Young Leaves from Edéa ; MLGA/YLGA : Mature Leaves/Young Leaves from Garoua ; MLMA/YLMA: Mature Leaves/Young Leaves from Maroua ; MLME/YLME :Mature Leaves/Young Leaves from Méiganga)

Figure $2 \mathrm{~b}$ Grouping of $M$. oleifera leaves powders according to their chemical composition [temperature $\left(\mathrm{T}^{\circ} \mathrm{C}\right)$ and precipitation $(\mathrm{p}$ mm) are supplementary variables]. 
Table 7 Pearson's Correlation Matrix.

\begin{tabular}{|c|c|c|c|c|c|c|c|c|c|c|c|c|c|c|c|c|c|c|c|}
\hline Variables & $\begin{array}{l}\text { Total } \\
\text { Ash }\end{array}$ & $\begin{array}{c}\text { Total } \\
\text { polyphenol }\end{array}$ & $\begin{array}{c}\text { Total } \\
\text { Tannins }\end{array}$ & Phytates & $\begin{array}{l}\text { Available } \\
\text { Carbohydrate. }\end{array}$ & $\begin{array}{l}\text { Total } \\
\text { Lipid }\end{array}$ & $\begin{array}{c}\text { Total } \\
\text { proteins }\end{array}$ & $\begin{array}{l}\text { Total } \\
\text { fiber }\end{array}$ & $\mathrm{Ca}$ & $\mathrm{Mg}$ & K & $\mathrm{Na}$ & $P$ & $\mathrm{Zn}$ & $\mathrm{Cu}$ & Mn & $\mathrm{Fe}$ & $\begin{array}{c}\text { Total } \\
\text { carotenoids }\end{array}$ & $\begin{array}{l}\text { Vitamin } \\
\mathrm{C}\end{array}$ \\
\hline Total Ash & & & & & & & & & & & & & & & & & & & \\
\hline Total polyphenol & 0.145 & & & & & & & & & & & & & & & & & & \\
\hline Total Tannins & 0.077 & 0.867 & & & & & & & & & & & & & & & & & \\
\hline Phytates & -0.168 & 0.487 & 0.485 & & & & & & & & & & & & & & & & \\
\hline $\begin{array}{l}\text { Available } \\
\text { Carbohydrate }\end{array}$ & -0.155 & -0.089 & -0.268 & -0.403 & & & & & & & & & & & & & & & \\
\hline Total lipids & -0.189 & -0.357 & -0.264 & 0.210 & -0.129 & & & & & & & & & & & & & & \\
\hline Total proteins & -0.203 & -0.257 & -0.136 & -0.119 & -0.475 & -0.067 & & & & & & & & & & & & & \\
\hline Total fibers & -0.012 & 0.265 & 0.401 & 0.518 & -0.878 & -0.113 & 0.231 & & & & & & & & & & & & \\
\hline $\mathrm{Ca}$ & 0.109 & 0.043 & 0.183 & 0.330 & -0.871 & 0.162 & 0.458 & 0.740 & & & & & & & & & & & \\
\hline $\mathrm{Mg}$ & 0.293 & 0.057 & 0.105 & 0.129 & -0.667 & 0.065 & 0.337 & 0.507 & 0.563 & & & & & & & & & & \\
\hline $\mathrm{K}$ & 0.495 & -0.103 & -0.328 & -0.385 & 0.390 & -0.126 & -0.055 & -0.575 & -0.366 & -0.099 & & & & & & & & & \\
\hline $\mathrm{Na}$ & 0.115 & -0.450 & -0.526 & -0.202 & -0.003 & 0.206 & 0.480 & -0.299 & 0.096 & 0.076 & 0.469 & & & & & & & & \\
\hline $\mathrm{P}$ & 0.362 & 0.024 & -0.002 & -0.484 & 0.271 & -0.199 & 0.035 & -0.431 & -0.448 & 0.101 & 0.726 & 0.257 & & & & & & & \\
\hline $\mathrm{Zn}$ & 0.189 & -0.218 & -0.376 & -0.574 & 0.496 & -0.069 & 0.022 & -0.651 & -0.623 & -0.078 & 0.791 & 0.387 & 0.873 & & & & & & \\
\hline $\mathrm{Cu}$ & -0.155 & 0.304 & 0.280 & 0.332 & -0.475 & 0.143 & 0.334 & 0.409 & 0.480 & 0.691 & -0.066 & 0.014 & 0.105 & -0.009 & & & & & \\
\hline Mn & -0.032 & 0.204 & 0.364 & 0.391 & -0.646 & 0.458 & 0.254 & 0.494 & 0.627 & 0.659 & -0.321 & -0.177 & -0.151 & -0.360 & 0.701 & & & & \\
\hline $\mathrm{Fe}$ & -0.017 & 0.229 & 0.360 & 0.436 & -0.868 & -0.081 & 0.384 & 0.893 & 0.880 & 0.626 & -0.448 & -0.085 & -0.353 & -0.570 & 0.626 & 0.549 & & & \\
\hline Total carotenoids & 0.274 & -0.517 & -0.638 & -0.328 & 0.261 & 0.207 & 0.188 & -0.545 & -0.376 & 0.024 & 0.707 & 0.650 & 0.567 & 0.765 & -0.112 & -0.262 & -0.490 & & \\
\hline Vitamin C & 0.050 & 0.212 & 0.072 & 0.265 & 0.061 & 0.061 & -0.269 & 0.001 & -0.053 & 0.010 & 0.008 & 0.030 & -0.224 & -0.209 & -0.192 & 0.038 & -0.088 & -0.177 & \\
\hline
\end{tabular}


In opposite, to polyphenols and tannins, the individual effect of locality and maturity as well as the interaction between them significantly $(\mathrm{p}=0.0001)$ influenced phytate content with locality showing a greater influence $(59 \%)$. Phytates are the main form of preservation of phosphorus in leaves. Phosphorus is an important mineral for the plants metabolism. According to Lestienne (2004), phytates have a tendency to accumulate in plant organs as they mature, which is in accordance with results obtained in this study. Mean values of phytate contents obtained in this study are $312.77 \mathrm{mg}$ per $100 \mathrm{~g}$ for young leaves and $340.04 \mathrm{mg}$ per $100 \mathrm{~g}$ DM for mature leaves; and are much lower than those reported (2.59 g per $100 \mathrm{~g}$ DM) by Ogbe \& Affiku (2011) for M. oleifera leaf powder in Lafia Nasarawa State (Nigeria). Phytates limit the bioavailability of minerals (iron, zinc, calcium) by chelating them (Connie \& Srimathi, 2002). Phytates in this study, show a significant negative correlation with zinc $(r=-0.574, \mathrm{p}<0.05$, Table 7$)$. This could indicate a chelating activity of Phytates on zinc. On the other hand, phytates possess antioxidant properties, and could play an important role in cell protection (John \& Feng, 2002).

4.2. Grouping of $M$. oleifera leaf powders according to their chemical composition

Much variation was observed in the chemical composition of young and mature leaves of $M$. oleifera from the different localities studied. Principal component analysis was thus carried out to group $M$. oleifera leaves according to similarities in their chemical composition. The first principal component (F1) represents $36.35 \%$ of variations between variables while the second principal component (F2) represents $18.28 \%$. Correlation circle (figure $2 \mathrm{a}$ ) shows grouping of variables. Five groups can be observed from this figure. The first group is composed mainly of the minerals $\mathrm{Mg}, \mathrm{Cu}, \mathrm{Mn}, \mathrm{Ca}, \mathrm{Fe}$; proteins and fiber. The second group consists of bioactive compounds (Phytates, total tannins, and total polyphenols) and the third group is made up solely of available carbohydrate. The fourth group is composed of $\mathrm{Na}, \mathrm{K}, \mathrm{P}, \mathrm{Zn}$ and carotenoids. The fifth group is not well represented on both the F1 and F2 axis and is made up of ash, lipids and vitamin C. Temperature and precipitation have no significant effects on these different groups. When we represent the factors $(M$. oleifera leaves at different maturity and from different localities) on these groups, we can separate them according to their major constituents (Figure $2 \mathrm{~b}$ and Table 6). Consequently, group 1 is characterized by mature leaves of $M$. oleifera from Mbouda, Bafia, Edea, Maroua, Doume and Meiganga which are rich in divalent cations, proteins and fiber contents. Thus mature leaves from these localities could contribute to solving nutritional deficiencies linked to proteins, $\mathrm{Fe}$, and $\mathrm{Ca}$. With respect to their high fiber content, they could help in facilitating digestion, and in the prevention of atherosclerosis and colon cancer (Gropper et al., 2009). The second group constituted of mature leaves of $M$. Oleifera from Bertoua is more concentrated in bioactive molecules and could be a good antioxidant source helping in the fight against stress related diseases (cardiovascular diseases, diabetes, cancer etc). The third group consists of young leaves from Meiganga, Doume, Bafia, Bertoua which are more concentrated in available carbohydrates contents, suggesting that they could be useful in the development of energetic foods. The fourth group, made up of young leaves of $M$. oleifera from Mbouda, Maroua, Edea and Garoua are good sources of sodium, potassium, phosphorus, total carotenoids (Vitamin A precursor) and zinc. Young leaves from these localities are thus important in alleviating vitamin $\mathrm{A}$ and zinc deficiencies. Their high potassium content suggests their use in the prevention and management of hypertension (Whitney \& Rolfes, 2011). The fifth group not well represented on F1-F2 axis is constituted by mature leaves of $M$. oleifera from Garoua and is characterized by good ash, lipids and vitamin $\mathrm{C}$ contents. This last group in addition to its nutritional role could be an important source of antioxidant. Table 6 give a summary of these different groups of $M$. oleifera leaf powders and their predominant constituents as well as their particular benefits with respect to health and nutrition.

\section{Conclusion}

The results of this study suggest that particular uses can be attributed to $M$. oleifera leaf powders from different localities and maturity, as the composition of these leaves vary significantly with locality and maturity. The grouping of $M$. oleifera leaves according to their chemical composition reveals that mature leaves are in general a rich source of protein, fiber, divalent cations, and bioactive compounds, and thus can help in the fight against protein, mineral deficiencies and stress related diseases. Young leaves are more concentrated in available carbohydrate, total carotenoids and monovalent cations. M. oleifera leaves of different stages of maturity and of different origins could thus be exploited for their unique nutritional and antioxidant benefits.

\section{Acknowledgement}

The authors would like to thank Mr TAGNE Théophile, Ibrahim SKIVO, Willy NGON and AWOUALA Balado of Moringa Cameroon network (MoCam) and Sister Monique of "Monastère St Benoît de Babeté" for their assistance with the collection of the samples.

\section{Conflict of interest}

Authors would hereby like to declare that there is no conflict of interests that could possibly arise.

\section{References}

Agoyi EE, Assogbadjo AE, Gouwakinnou G, Okou FAY, Sinsin B (2014) Ethnobotanical Assessment of Moringa oleifera Lam. in Southern Benin (West Africa). Ethnobotany Research and Applications 12: 551-560. doi:http://dx.doi.org/10.17348/era.12.0.551-560. 
AOAC (1975) Methods of analysis of the Association of Official Analytical Chemists, $10^{\text {th }}$ edition, Washington DC, USA.

AOAC (1990) Methods of analysis of the Association of Official Analytical Chemists. $15^{\text {th }}$ edition, Arlington, Virginia 22201, USA.

Armelle, de SS, Mélanie B (2010) Produire et transformer les feuilles de Moringa (MAG: Moringa Association of Ghana) Réseau Moringa et Plantes Ressources 211Paris, France: Moringanews, Pp. 9-12.

Bamishaiye EI, Olayemi FF, Awagu EF, Bamshaiye OM (2011) Proximate and phytochemical composition of Moringa oleifera leaves at three stages of maturation. Advance Journal of Food Science and Technology 3: 233-237.

Belitz HD, Grosch W, Schieberle P (2009) Food Chemistry, $4^{\text {th }}$ edn. Springer, Berlin, Pp. 239-245.

Biswas SK, Chowdhury A, Das J, Roy A, Hosen SMZ (2012) Pharmacological potentials of Moringa oleifera Lam.: a review. International Journal of Pharmaceutical Sciences and Research 3: 305-310

Bourely J (1982) Observation sur le dosage de l'huile des graines de cotonnier. Coton et Fibres Tropicales 27: 183-196.

Cheftel JC, Cheftel H, Besançon P (1984) Introduction à la biochimie et à la technologie des aliments, $4^{\text {ème }}$ édition.Lavoisier, Paris.

Connie MW, Srimathi K (2002) Phytate and Mineral Biovailability. In: Reddy NR \& Sathe SK (Eds) Food Phytates. CRC Press, Boca Raton, Pp 201-213.

Djuikwo VN, Ejoh AR, Gouado I, Mbofung CM, Tanumihardjo SA (2011) Determination of Major Carotenoids in Processed Tropical Leafy Vegetables Indigenous to Africa. Food and Nutrition Sciences 2: 793-802.

Fahey JW (2005) Moringa oléiféra: A review of the Medical Evidence for its Nutritional, Therapeutic, and Prophylactic properties. Part 1.Trees for life Journal1:5.

Fischer E, Stein EA (1961) DNS colorimetric determination of available carbohydrates in foods. Biochemical Preparation 8: 30-37.

Folly P (2000) Catabolisme de la chlorophylle b, structure, mécanismes et synthèses. Thèse de $\mathrm{PhD}$ submitted to Université de Fribourg, Suisse.

Foulk J, Danny A, Roy D, Chad U (2011) Production of FlaxFiber for Biocomposites. In: Kalia S, Kaith BS, Kaur I (Eds) Cellulose Fibers: Bio-and Nano-Polymer Composites green chemistry and technology. Springer-Verlag, Berlin, Pp 61-95.

Gropper SS, Smith JL, Groff JL (2009) Advanced Nutrition and Human Metabolism, $5^{\text {th }}$ edn.Wadsworth, Belmont, Pp 1426.

Jenab M, Chen J, Thompson LU (2001) Sialomucin production in aberrant crypt foci relates to degree of dysplasia and rate of cell proliferation. Cancer Letters165: 19-25. doi: http://dx.doi.org/10.1016/S0304-3835(00)00706-0

John RB, Feng G (2002) The Antioxidant Effects of Inositol Phosphates In: Reddy NR,Sathe SK (Eds) Food Phytates. CRC Press, Boca Raton, Pp 181-190.

Jones BJ, Vernon CW (1990) Sampling, handling and analyzing plant tissue samples. In: Westerman RL (Ed) Soil Testing and Plant Analysis, 3rd edn, Soil Science Society of America Book Series 3.

Jongrungruangchok S, Bunrathep S, Songsak T (2010) Nutrients and minerals content of eleven different samples of Moringa oleifera cultivated in Thailand. Journal of Health Resources 24: 123-127.

Kengué J, Ebete MA, Ntsengue LJ, Assoumou H, Fondi EN (2008)Etat des ressources phytochimiques pour l'alimentation et l'agriculture au Cameroun - Deuxième rapport. Institut de Recherche Agricole pour le Développement (IRAD), Yaoundé, Pp 20-23.

Kirkby EA, Pilbeam DJ (1984) Calcium as a plant nutrient. Plant, Cell and Environment 7: 397-405.

Koolman J, Roehm KH (2005) Color atlas of biochemistry ( $2^{\text {nd }}$ edn). Appl, Wemding, Stuttgart, Pp. 129-132.

Kumar PS, Mishra D, Ghosh G, Chandra S. Panda GS (2010) Medicinal uses and pharmacological properties of Moringa oleifera. International Journal of Phytomedicine 2: 210-216.

Lestienne I (2004) Contribution à l'étude de la biodisponibilité du fer et du zinc dans le grain de mil et conditions d'amélioration dans les aliments de complément. Thèse de $\mathrm{PhD}$, Université de Montpellier II, France.

Makkar HPS, Blümmel M, Borowy NK, Becker K (1993) Gravimetric determination of tannins and their correlations with chemical and protein precipitation methods. Journal of the Science of Food and Agriculture 61: 161-165. doi: 10.1002/jsfa.2740610205.

Moyo B, Masika PJ, Hugo A, Muchenje V (2011) Nutritional characterization of Moringa (Moringa oleifera Lam.) leaves. African Journal of Biotechnology10: 12925-12933.doi: 10.5897/AJB10.1599 
Murphy J, Riley JP (1962) A modified single solution method for determination of phosphate in natural waters. Analytica Chimica Acta 27: 31-36. doi:10.1016/S0003-2670(00)88444-5.

Oduro I, Ellis WO, Owusu D (2008) Nutritional potential of two leafy vegetables: Moringaoleifera and Ipomoea batatas leaves. Scientific Research and Essay 3: 057-060.

Ogbe AO, Affiku JP (2011) Proximate study, mineral and antinutrient composition of Moringa oleifera leaves harvested from Lafia, Nigeria: potential benefits in poultry nutrition and health.Journal of Microbiology, Biotechnology and Food Sciences 1: 296-308.

Sánchez-Machado DI, Nññez-Gastélum JA, López-Cervantes J, Reyes-Moreno C, Ramírez-Wong B (2010) Nutritional quality of edible parts of Moringa oleifera. Food Analytical Methods 3 : 175-180. doi: 10.1007/s12161-009-9106-z.

Sarni-Manchado P, Cheynier V (2006) Les polyphénols en agroalimentaire.Lavoisier, Paris, Pp 50-56.

Shih MC, Chang CM, Kang SM, Tsai ML (2011) Effect of Different Parts (Leaf, Stem and Stalk) and Seasons (Summer and Winter) on the Chemical Compositions and Antioxidant Activity of Moringa oleifera. International Journal of Molecular Sciences 12: 6077-6088. doi:10.3390/ijms 12096077

Tchiégang C, Kitikil A (2004) Données ethno nutritionnelles et caractéristiques physico-chimiques des légumes-feuilles consommés dans la savane de l'Adamaoua (Cameroun) Tropicultura 22: 11-18.
Tomohiro S (1990) Laboratory Manual for Food Analysis.JomoKenyata University College of Agriculture and Technology, Kenya.

Vaintraub IA, Lapteva NA (1988) Colorimetric determination of phytates in unpurified extracts of seeds and the products of their processing. Analysis Biochemistry175:227-230. doi:10.1016/0003-2697(88)90382-X.

Whitney E, Rolfes SR (2011) Understanding Nutrition(12 ${ }^{\text {th }}$ edn).Wadsworth, Belmont, Pp398-400.

Wolff JP (1968). Manuel d'analyse des corps gras. Azoulayéd, Paris.

Yameogo CW, Bengaly MD, Savadogo A, Nikiema PA, Traore SA (2011) Determination of Chemical composition and Nutritional Values of Moringaoleifera leaves. Pakistan Journal of Nutrition 10: 264-268.

Yang RY, Chang LC, Hsu JC, Weng BBC, Palada MC, Chadha ML, Levasseur V (2006) Online reference included in article Nutritional and functional properties of Moringa leavesFrom germoplasm, to plant, to food, to health available on http://miracletrees.org/moringa-doc/from-germplasm-to-plantto-food-to-health.pdf Accessed 12/11/2014.

Zufferey VJU (2000). Echanges gazeux des feuilles chez Vitis vinifera L. (cv. chasselas) en fonction des paramètres climatiques et physiologiques et des modes de conduites de la vigne. Thèse de $\mathrm{PhD}$, Ecole polytechnique fédérale, Zurich, Suisse. 